\title{
A influência da concepção de educação grega na constituição histórica da paideia cristã
}

\author{
Charles Lamartine de Sousa Freitas ${ }^{1}$
}

\begin{abstract}
Resumo
Neste artigo, pretendemos abordar os elementos educacionais da Grécia antiga, fundamentais tanto para a formação e o desenvolvimento da cultura ocidental como para a constituição da paideia cristã da antiguidade. Destacamos como a idealização do épos deu lugar à formação do cidadão a partir do ideal de uma areté política que, no período helenístico, tendo seu apogeu na pólis grega, vai ser alternado por outros valores mais ligados à individualidade. Nesse sentido, consideramos que a paideia grega, em seus diferentes momentos, vai ser elemento chave para a construção de uma paideia cristã. Esta, por sua vez além de sintetizar elementos universalistas do pensamento grego, se nutre de um tempo oportuno, de um kairós para expandir a mensagem cristã oriunda das promessas da religião judaica de um messiah para a universalidade dos homens, cuja expressão vai ser fundamental para a construção dos valores da sociedade ocidental.
\end{abstract}

Palavras-chave: Paideia grega. Paideia cristã. Cristianismo. Civitas. Areté.

\begin{abstract}
In this article we intend to address the educational elements of ancient Greece, which are fundamental for the formation and development of Western culture, they are also important for the constitution of the Christian paideia of antiquity. We emphasize how the ideal of the formation of the épos gave rise to the formation of the citizen from the ideal of a political areté that having its apogee in the Greek polis will be alternated by other values, more linked to the individuality, in the Hellenistic period. In this sense, we consider that the Greek paideia in its different moments will be a key element for the construction of a Christian paideia that, in addition to synthesizing universalistic elements of Greek thought, nourishes itself with an opportune time, of a kairós to expand the Christian message, deriving from the promises of the Jewish
\end{abstract}

\footnotetext{
${ }^{1}$ Graduado em Serviço Social, pela Universidade do Estado do Rio Grande do Norte (UERN), e em Teologia, pelo Ateneo Pontificio Regina Apostolorum - Roma/Itália. Especialista em Metodologia e Docência do Ensino Superior, pela Faculdade do Vale do Jaguaribe (FVJ). Mestre em Teologia, pela Pontifícia Universidade Gregoriana Roma/Itália. Mestrando do Programa de Pós-Graduação em Educação da Universidade do Estado do Rio Grande do Norte. Atualmente é Professor e Diretor Geral da Faculdade Diocesana de Mossoró (FDM). Tem desenvolvido atividades acadêmicas na área de Teologia, Filosofia e Educação, atuando principalmente nos seguintes temas: Teologia Sistemática, História da Literatura Cristã Antiga, História e Filosofia da Educação, Metodologia da História Oral e (Auto)Biografia.
} 
religion of a messiah, to the universality of men, whose expression will be fundamental to the construction of the values of Western society.

Keywords: Greek Paideia. Christian Paideia. Christianity. Civitas. Areté

\section{Introdução}

O homem, enquanto ser da natureza e, ao mesmo tempo, afastado dela em relação ao seu aparato instintivo menos predominante do que o dos demais seres animais, precisa se constituir para além de suas carências. Nesse interstício, assoma o papel da educação, que o constitui enquanto sapiens, hominizando-o, por assim dizer, e preparando-o para a sobrevivência em meio às vicissitudes e possibilidades do seu entorno.

Diante do importante papel da educação nas sociedades humanas, pretendemos estabelecer uma relação entre dois modelos educacionais fundamentais para a constituição do pensamento ocidental - a paideia grega e a cristã -, destacando a influência da primeira sobre a segunda e apontando seus lugares, temáticas e valores partilhados e específicos.

Desde já, podemos apontar que o objeto principal de tais modelos é o homem. Entretanto, enquanto na evolução do pensamento grego o épos deu lugar ao cidadão, mediante um processo que vai da atividade guerreira (no campo de batalha) ao processo de imersão do homem na coletividade (a ágora), passando pelo retorno ao individualismo do período helenístico, na antiguidade tardia, houve o desenvolvimento, em um tempo oportuno (um kairós), de um novo modelo de pensamento, o cristão, que vai assumir uma tarefa universalizante de abertura para todos os homens; um convite à participação individual e política em um novo tipo de coletividade, a civitas Dei.

Tais modelos são o fundamento para o que chamamos de sociedade ocidental e considerá-los nesta discussão consiste não somente em realizarmos um esforço para interpretar uma história e repensar uma herança, mas também para apontar caminhos em direção a uma educação humanizante e para todos em tempos difíceis: tempos de radicalizações, 
segregacionismos, golpes políticos e tensões sociais. Frente a esse cenário, "temos a tarefa de repassar para as novas gerações um conjunto de valores, de experiências de sentido, de inspirações internas e externas, de imperativos éticos e de convencimentos estéticos, para a produção dos comportamentos consensuados em sociedade.” (NUNES, 2018, p. 08). Em outras palavras, temos a missão de pensar a paideia cristã, que aqui representa caminhos para uma educação que se abre a todos os homens; que pode e deve acontecer em um tempo que se fecha mais e mais para o homem e a humanidade.

\section{O modelo de educação clássica grega}

Ao discutirmos o tema da Pedagogia e sua história é de caráter indispensável estudar a concepção clássica advinda do mundo grego, pois foi essa sociedade que construiu solidamente uma das primeiras compreensões da Educação e do valor da Escola no processo ideal de formação integral do homem. Tendo como ênfase a busca da implicação do homem com a polis, os gregos pensaram um processo educacional voltado para a vida política. Eles consolidaram, em uma longa trajetória, o conceito de Paideia, que não se limita à instrução das crianças, mas representa uma das mais importantes páginas na formação da Cultura e Pedagogia Ocidental (NUNES, 2018). Tal concepção é asseverada por Jaeger, que assim afirma:

A formação do homem grego, a paidéia, no seu caráter particular e no seu desenvolvimento histórico, não se trata de um conjunto de ideias abstratas, mas da própria história da Grécia na realidade concreta do seu destino vital. Contudo, essa história vivida já teria desaparecido há longo tempo se o homem grego não a tivesse criado na sua forma perene. Criou-se como expressão da altíssima vontade com que talhou o seu destino. Nos estádios primitivos do seu crescimento, não teve a ideia clara dessa vontade; mas, à medida que avançava no seu caminho, ia-se gravando na sua consciência, com clareza cada vez maior, a finalidade sempre presente em que a sua vida assentava: a

Filos. e Educ., Campinas, SP, v.10, n.2, p.287-309, maio/ago. 2018 - ISSN 1984-9605 
formação de um elevado tipo de Homem. A ideia de educação representava para ele o sentido de todo o esforço humano. [...] E foi sob a forma de paidéia, de 'cultura', que os gregos consideraram a totalidade da sua obra criadora em relação aos outros povos da Antiguidade de que foram herdeiros. (JAEGER, 2013, p. 05, grifos do autor).

Como podemos perceber nas palavras de Jaeger, o magno princípio educativo grego tem sua evolução organizada historicamente e não de modo imediato. A edificação dessa concepção é resultado de uma reflexão que perpassa anos, em um processo de longo amadurecimento, o qual, $a$ posteriori, resultará numa construção dialógica de saberes. Nessa perspectiva, buscaremos apresentar, nas próximas linhas, alguns apontamentos sobre a história da educação no mundo grego antigo e seus autores, reconhecendo o valor desse construto intelectual para humanidade.

\subsection{De Homero à Paideia Grega}

A tradição que nos vem de Platão aponta para a influência dos mitos e da poesia grega na educação do homem grego. Homero, nesse sentido, consiste na principal referência. Na Ilíada e na Odisseia, suas obras primas, temos o modelo do ideal guerreiro, expresso na figura do épos, cuja virtude consistia em cumprir uma destinação, com apoio e ajuda dos deuses. Odisseu ou Ulisses, é, portanto, o guerreiro cuja astúcia tinha inspiração na deusa Athena.

Homero consiste, então, no paradigma básico dos primórdios da educação grega. Como nos diz Bortolini (2018, p. 28), "além do ideal do homem, o espírito aristocrático exercia forte influência na sociedade grega, a areté tornava-se para os gregos a excelência humana e atributo da nobreza". Os poemas homéricos e, por outro lado, os de Hesíodo, se tornam, portanto, o elemento central da formação das classes aristocráticas, bem como o elemento estutural constitutivo da tradição oral repassada aos 
demais grupos sociais na atividade do poeta rapsodo. Para Vieira (2018, p. 170):

[...] é em Homero e nos chamados poemas homéricos que o ideal educativo do homem grego aparece originalmente formulado e explicitado, por meio do conceito de areté. Trata-se de um ideal transmitido de forma oral, por meio dos poetas, a partir dos quais podemos notar os valores que um homem heroico, aristocrata, guerreiro e político de destaque deveria possuir nesse momento [...] (VIEIRA, 2018, p. 170, grifos do autor)

$\mathrm{O}$ ideal do guerreiro se mostra, então, fundamental em uma sociedade aristocrática que cultiva valores individuais, se constitui uma areté voltada para a elite em seu caráter nobiliárquico, destinada à condução dos negócios familiares e mesmo políticos. Em complemento Bortolini (2018, p.30) afirma:

O período homérico e arcaico se distingue por meio de uma educação do exemplo, tinha como educador Homero no século X a.C com obras historicamente conhecida como Odisseia e Iliada e Hesiodo no século VIII a.C com as obras Teogonia e Trabalhos e Dias, tornarampse essenciais para a educação grega arcaica. A arete, nesse contexto, está relacionada a formação do heróis, destinada a juventude aristocrata. Os poemas homéricos constituíram por séculos os ideais educativos da classe dominante.

Tal visão vai ser expressa em outras produções literárias gregas, como nas tragédias, que apontam para esse agir individual cuja expressão maior é a úbris, algo que remete à ideia de fado, lida, destinação que envolve o homem em uma trama maior que ele, pois contempla os deuses. Por outro lado, o exercício de determinadas virtudes que levam ao excesso visa expressar a dimensão do agir individual, que realiza um grande feito. 
Em síntese, o conceito homérico de areté "[...] representa um ideal que serve de modelo para a formação do homem 'perfeito', através do aperfeiçoamento do corpo, da alma, da oratória, das boas ações e da ética" (VIEIRA, 2018, p. 05).

A educação baseada em Homero subsiste até o período do desenvolvimento da pólis grega, quando a perspectiva do homem em sociedade, de uma atividade e de virtudes voltadas para a coletividade vai suplantar o ideal do épos. Nesse momento, se constituem e se fundam novas características, tanto para a areté, quanto para a constituição do homem, tendo por base outros referenciais mais adequados ao novo momento histórico e aos desenvolvimentos da cultura grega.

Com o início da constituição da pólis, entre VIII e VII a.C, inicia-se uma nova fase, a organização do Estado político grego vai se modificando na medida em que a mesma vai se constituindo em cidade-estado com forte unidade espiritual, no sentido religioso e mitopoietico. (BORTOLINI, 2018, p. 31)

Este novo ideal de educação e de formação do homem, que podemos associar à forma, formação, ao conceito de ideia, foi bem trabalhado por Werner Jaeger, em sua obra denominada de Paideia. Consiste na formação integral do homem tendo em vista o exercício de uma vida social e política, sob um novo conceito de coletividade. A paideia está, deste modo, associada a um momento histórico e social preciso. Como bem salienta Jaeger (2013, p. 23): “[...] não se pode utilizar a história da palavra Paideia como fio condutor para estudar a origem da educação grega, porque esta palavra só aparece no séc. V a.C.”.

Por paideia entende-se, então, a formação integral da criança, do paidós, daquele que se pretende que assuma uma forma, ideia adequada às disposições necessárias à vida na pólis. Paideia pode ser compreendida, portanto, como a formação do homem que tem suas potências na criança, entendendo-se que a formação começa desde cedo. Desnecessário é indicar 
que na República Platão já apontava para um longo período de formação que começava na infância.

\subsection{Os elementos presentes na Paideia Grega}

O trabalho minucioso e preciso de Jaeger (2013) nos faz acompanhar o processo, os momentos e os autores que vêm apresentar a paideia grega desde seus primórdios ao seu aspecto mais definido na figura de Platão. Inútil lembrar que esse processo nem sempre foi tão bem idealizado e estruturado, uma vez que a própria cultura grega, por assim dizer, composta de várias cidades-Estado, assumiu diferentes posturas face à autonomia e à autarquia dessas pólis. Sendo assim:

[...] vale ressaltar que no princípio, em estágios primitivos da cultura grega, não havia a clareza da finalidade da formação de um modelo elevado de homem, à medida em que o tempo avançava esse ideal de homem vai se gravando na consciência da cultura grega, com clareza cada vez maior. (BORTOLINI, 2018, p. 29).

Fica claro, portanto, que o desenvolvimento da educação grega se estabeleceu por etapas mais ou menos definidas e que tiveram como elemento principal a aquisição dos conhecimentos básicos sobre os quais há que se desenvolver outras habilidades e competências. Acerca desse processo, Cambi (1999) nos informa que, no primórdios da educação grega, a educação dada aos rapazes bem nascidos, obviamente, consistia não somente em conteúdos, mas no cuidado que alguns mestres dedicavam a esses aprendentes.

Numa primeira fase, a educação clássica era dada aos rapazes que frequentavam a escola e a palestra, onde eram instruídos através da leitura, da escrita, da música e da educação física, esse período era marcado pela presença de três instrutores: o grammatistes (professor 
de gramática), o kitharistes (professor de música), o paidotribes (mestre). (CAMBI, 1999, p. 83, grifos do autor).

Entretanto, essa forma de educação não é, de fato, o diferencial entre os gregos, pois, em certo sentido, no que tange aos processos educativos nas demais sociedades, essa relação com conteúdos e com mestres é assaz corriqueira e não extensiva a todas as pessoas, aos grupos sociais, etc. O novo dessa educação consiste, então, em comportar uma noção de homem que vai ser o pilar da ideia de formação ocidental a culminar com a determinação de um humanismo. Em outras palavras :"É pelo caráter natural e universal que os gregos atribuem a educação um sentido moral e prático, preocupados com a formação integral do homem, apresentam o humanismo como princípio.” (BORTOLINI, 2018, p. 28)

Nesse sentido, os gregos desenvolvem uma concepção diferencial de educação que está para além de uma formação básica, aquela que, em muitas culturas orientais, por exemplo, visava a educação mínima, normalmente para o exercício de uma atividade burocrática. Na verdade, os gregos consideraram formação um processo continuado, interior e exterior, calcado em virtudes e que visavam a totalidade do homem. De modo mais claro :

Os gregos distinguem educação de formação, dada as especificidades de cada uma. O termo formação geralmente é associado a aprendizagens externas e atitude interior, as quais se manifestam numa forma integral no homem, e que só termina com o termino da existência humana. Platão esboça nas leis que 'a essência de toda a verdadeira educação ou paideia', é baseada na 'arete que enche o homem do desejo e da ânsia de se tornar um cidadão perfeito e o ensina a mandar e obedecer, sobre o fundamento da justiça'. (BORTOLINI, 2018, p. 33, grifos do autor).

Platão, de fato representa um dos principais autores em que podemos ver, de forma estruturada, os elementos mais gerais da paideia grega. 
Contudo, vale lembrar que, quanto à extensão desse processo, principalmente na Repúblicas, o filósofo o nutre de vários elementos da educação espartana. É necessário ressaltar que a espartophilia de Platão não era algo restrito a esse pensador.

O modelo de educação de Esparta, seus princípios, valores e aplicação, serão, pois, fundamentais para a cultura grega, assim como o que se desenvolve em Atenas também servirá de modelo para outras cidades gregas, uma vez que essas duas cidades-Estado serão, por longos períodos de hegemonia de cada uma dessas partes, o centro das decisões políticas da Grécia, quer se unindo, quer se opondo uma à outra (vide as guerras médicas e a do Peloponeso, respectivamente).

Devemos lembrar que Esparta era uma diarquia, uma sociedade guerreira e a educação nela praticada começava em uma idade bem jovem, quando o aprendiz tinha que começar suportando os rigores da vida de um épos. Esse longo processo levava à maturidade. Suportar o frio, a dor, aprender a controlar o próprio corpo e a mente, bem como a prender a agir em grupo no meio da batalha eram características desse aprendizado. Nesse sentido, a educação de Esparta concilia as virtudes do guerreiro, próprias da educação inspirada em Homero, com as virtudes da vida cívica.

Em Atenas, Platão vai ser o maior expoente desse modelo de educação. Baseado nesses princípios, bem como no cumprindo do desafio de combater a influência dos sofistas e seguir, ao mesmo tempo, os princípios da educação das virtudes aristocráticas, na República, o ateniense expõe um ideal que viria a ser o modelo da educação grega. Vale salientar que o modelo platônico se inspira na educação grega de modo geral e promove uma adequação ao que, segundo o ateniense, estaria em conformidade com a razão. (LESKY, 1995)

No ideal platônico, a formação começava na tenra idade, as crianças eram separadas de suas famílias e postas à disposição do Estado. Essa formação considerava as aptidões que os indivíduos tinham em si e visava desenvolver e aprimorar as virtudes associadas à cada uma dessas "vocações". O processo não era fixo, ou seja, as pessoas podiam aprofundar 
aptidões, mostrar aptidões novas, embora isso nem sempre seja reconhecido em Platão, julgado como inimigo da liberdade e defensor da aristocracia, algo que não faz jus ao pensador grego. No seu ideal está presente uma concepção grega de homem e de educação que vai ser cara ao ocidente. Conforme essa concepção :

Educar implica em reconhecer que a condição humana é aprendida, que é historicamente produzida, que a educação é um projeto definido no tempo e no espaço humano e natural. Significa formar o homem, engendrar, isto é, fazer produzir, a pessoa humana, para a vida em sociedade. Implica em reconhecer que a tarefa de fazer-se homem, a hominização de si, renova-se a cada nascimento, a casa geração, a cada criança. (BORTOLINI, 2018, p. 23)

Para Platão, a formação deveria levar em consideração a totalidade do homem, que, desde Sócrates, vai estar associada à alma. Mas não há uma dissociação, quando se considera que a alma é a totalidade do homem. Essa educação vai considerar o desenvolvimento da racionalidade e da corporeidade, presentes na música, na matemática, na astronomia e na ginástica. Em certo sentido, essas "disciplinas" se correlacionam. Em cada uma e entre elas existe uma harmonia, uma totalidade que vai configurar a estrutura do cosmos, enquanto universalidade, da cidade, enquanto particularidade, e do homem, enquanto singularidade.

Desse quadro de relações que, no fundo, são uma expressão da própria filosofia e racionalidade que vai se desenvolver e, continuamente, desenvolver a sociedade ocidental, é que se formou a paideia grega, esforço fundamental para o desenvolvimento da humanidade como um todo. A essa paideia vai se submeter o próprio invasor romano e, apesar da destruição do quadro político que viu nascer essa paideia, ela vai permanecer como modelo geral da formação integral do homem. (LESKY, 1995).

\subsection{Da Paideia Grega ao Período Helenístico}


O modelo de paideia que foi desenvolvido durante o período clássico subsistiu até o período helenístico, mas, quando da invasão de Felipe II, e, subsequentemente, dos desenvolvimentos empreendidos por seu filho Alexandre, o grande, aconteceram mudanças em função das transformações sofridas pela cidade grega, tanto no espaço político, com suas consequências para o homem da aristocracia, quanto para o homem comum. Nesse período temos a passagem do espaço público da cidade para o espaço político do império, algo que impeliu uma profunda transformação no ideal de formação, tendo em vista seus pressupostos e fins impostos pela nova realidade.

\subsubsection{Da Pólis a Cosmópolis}

Do processo educacional, que, sendo levado adiante pelos sofistas na sua relação dialética com o pensamento socrático-platônico, foi constitutivo da pólis grega, do cidadão capaz de participar da vida política - cidadão este bem formado quanto ao corpo, ciente de suas responsabilidades com a cidade, preparado para assumir determinadas funções no espaço público, pronto a colocar a coletividade, espaço e condição de possibilidade de seu desenvolvimento pleno, em primeiro lugar -, passamos a um novo modelo, o da cosmópolis. Deste modo:

O nosso estudo deu-nos repetidas ocasiões para falarmos da ruptura daqueles vínculos que tinha determinado a estrutura da pólis clássica. [...] em conexão com isto está a consumação daquele processo que, no século IV, fez com que o individualismo ganhasse constantemente terreno, e está também o pressentimento de outras relações de mais amplo alcance nos melhores da época. O indivíduo tem uma vida difícil, pois a luta pela existência aumentou a sua dureza. Terminou a época das indenizações que o Estado concedia pela participação na assembleia popular e na administração da justiça. Tal coisa 
passa a ser como o sinal distintivo duma democracia extrema passada de moda. Os antagonismos sociais acentuaram-se. O pobre diabo, cujo sonho dourado era o alijar de cargas e a repartição de terras, tinha que lutar rudemente para assegurar o mínimo para a sua existência no meio de salários decrescentes e da forte concorrência dos escravos. (LESKY, 1995, p. 678).

No espaço da ágora, há a substituição dos debates públicos, da aceitação tácita das leis da cidade e do compromisso e responsabilidade de cumprir tarefas consideradas como justas (como aconteceu com Sócrates, que não fugiu da cidade após sua condenação, como queriam seus discípulos, mas que refutou, anteriormente, cumprir ordens que ele considerou como injustas), pela estrutura do império macedônico, pela descentração da cidade e deslocamento do poder e das decisões para a capital do império. Esse distanciamento inviabilizava a efetividade da areté política e a promoção de um novo modelo de areté.

Longe do espaço público em meio ao qual o homem grego encontrava o sentido de sua formação e a expressão prática de sua existência - uma vez que sua voz era ouvida e as decisões que afetavam sua vida eram expressas e decididas no espaço público -, o homem do período helenístico não tem a cidade como referência. Sua voz está posta em meio a tantas outras em um império de dimensões geográficas que fazem com que a expressão pública de sua vontade e de sua voz se dilua até o aniquilamento. Desse modo, é forçado a buscar uma forma de exercer a vida resguardando o espaço do significado da existência. Assim, surgem, num período considerado decadente, filosofias que vão dar novos tônus à existência humana, agora num sentido mais individual, única instância em que pode o homem desenvolver-se e buscar sua felicidade. Em contrapartida, vimos que:

O fato político e econômico que decreta, em parte, ou acelera ainda mais este processo, o fim das fronteiras regionais do 
mundo antigo é o Helenismo, a expansão do 'modus vivendi' grego imposto ao resto do mundo conhecido, através das conquistas de Alexandre Magno (séculos III e II a.C.). [...] O grego desde período quer tornar-se autossuficiente, realizar em si o ideal de 'autarkèia', a completa autonomia e despojamento individual. Já não se sente como um cidadão de uma determinada 'pólis', da qual antes tanto se orgulhava; ao contrário, que desprender-se de todos os laços familiares religiosos ou de pertença a uma determinada 'pólis' (cidadania). Estas filosofias têm em comum um retorno ao ideal sábio, como homem universal, cidadão do mundo (Kosmópolis) sem qualquer característica particularizante ou 'nacional'. (NUNES, 1987, pp. 38-39, grifos do autor).

Neste sentido, as "escolas" helenísticas, especificamente o estoicismo, o epicurismo e o ceticismo, vão florescer, não por acaso, associadas a uma lógica, a uma física e a uma ética que se interligam destacando o aspecto material da vida e a busca individual pelas soluções dos problemas da existência. Os elementos que compõem esse novo ideal de formação do homem se baseiam em "virtudes" como a apathia, a aponia, a ataraxia. Em oposição ao elenchos sofístico-socrático, encontramos a epoché, com mudanças significativas que apontam para essa transformação do espaço da pólis para a cosmópolis.

No espaço público da pólis e do seu ideal formativo do cidadão, vemos o desenvolvimento de um ideal de formação universalista, já no espaço restrito temos a educação dos bem-nascidos. Temos um alargamento do ideal de "escola", que inclui as mulheres e os escravos de uma comunidade localizada, baseada em uma aiskésis que visa o indivíduo. No espaço da Cosmópolis, por sua vez, vige um tipo de formação cuja pretensão é dar ao homem, imerso em um espaço público anônimo, a possibilidade de se desenvolver e encontrar a felicidade por meio de seus próprios esforços e dos elementos que ele tem à disposição, desenvolvendo 
aspectos fundamentais de sua autonomia e autarquia, ou seja, do ideal socrático, em um nível individual. (NUNES, 1987)

\section{Os primórdios do cristianismo}

Na passagem do período helenístico para o que se conceituou como antiguidade grega ou antiguidade cristã, temos o surgimento do cristianismo. Sabe-se que a expansão do Império Romano contou com uma estratégia utilizada por Alexandre, o Grande, de manter determinadas regiões dominadas sob a égide do poder local. Nesse sentido, a Judeia, apesar do domínio romano, estava sob o poder das autoridades judaicas. Em meio a esse período, surge o que, inicialmente, foi considerada uma seita, dentre as várias presentes no seio do judaísmo. Seu início se deu com a pregação de João, o Batista, e continuou com a figura do messiah, ou seja, do Cristo, na pessoa de Jesus. Importa salientar que essas "expressões, títulos e figuras" têm um rico sentido para a população judaica, que viveu sob vários tipos de opressão, entre elas a romana.

O Cristo, celebrado na figura de Jesus de Nazaré, encarna a promessa que tem, na profecia de Isaias, a sua mais perfeita expressão, a do libertador para o povo sofrido e oprimido. Essa esperança messiânica se mistura com uma dimensão política que, no período do Império Romano, encontrou condições de possibilidade de efetivação.

A expansão do cristianismo ocorre no momento de declínio das estruturas imperiais do mundo antigo, sobretudo das bases políticas e culturais greco-romanas. Nesse cenário, a pregação de Jesus sobre o Reino de Deus, que nutre em seu seio os desejos de promoção da justiça e da paz, se apresenta como a "Boa-Nova" destinada a todos. A nova religião prega "a igualdade de todos os homens[...] uma outra vida para os sofridos e Pobres, a Caridade para com o próximo" (NUNES, 1987, p. 41).

Nascido em meio às camadas mais pobres da sociedade judaica, o cristianismo vai ser considerado como uma dissidência do judaísmo quanto ao seu conteúdo e a sua forma, visto que Jesus prega o amor ao próximo, o

Filos. e Educ., Campinas, SP, v.10, n.2, p.287-309, maio/ago. 2018 - ISSN 1984-9605 
dar a outra face a quem te ofende e, ademais, anda em meio aos pobres, aos cobradores de impostos, aos deficientes e prostitutas. Jesus é considerado o messias diferente, que anda em meio ao povo e vive com eles e que, desde o início, sofre as mesmas perseguições.

Por não ser uma manifestação religiosa das e para as elites judaicas, em seus primórdios o cristianismo já apresenta sua vocação universalista: aceita em seu entorno as mais diversas pessoas e classes sociais, aqueles que falam em seu nome, muito embora não o acompanhem de perto; empreende um périplo pelas regiões da Galileia, Samaria e Judeia dando, desde o início, esse aspecto para além das fronteiras de sua mensagem. (NUNES, 1987).

O projeto histórico-social do cristianismo revela-se de maneira simbólica na última grande preleção de $\mathrm{Jesus}^{2}$, ao retornar ao seu reino, assim testemunhado pelos seus seguidores: Ite, eunte omnes docete - Ide, ensinai a todos (MATEUS 28,19). Posto isso, Manacorda (2010) reconhece a vinculação entre a dimensão religiosa do cristianismo e sua original dimensão pedagógica, afinal, converter e espalhar o reino é educar para a fé. A fé no cristianismo, nesse sentido, é uma matéria de educação: a Didaqué. Então, nessa interpretação, a Paideia Cristã pode ser considerada como a primeira grande proposição universalista de uma conversão ou de uma salvação para todos os homens - numa linguagem religiosa -, o que corresponderia, em termos de política educacional, a uma proposta democrática e universalista ${ }^{3}$ de possibilidade de ensino e de aprendizagem.

\subsection{O ambiente espiritual do mundo romano: o Kairós}

Um dos aspectos do desenvolvimento do cristianismo tem a ver com as condições históricas, políticas e sociais promovidas pelo Império Romano. O alargamento das fronteiras, a pax romana, as estradas, a centralização do poder, o acesso a várias culturas e religiosidades dentro do

\footnotetext{
${ }^{2}$ Tomamos aqui a figura histórica e o significado teológico e cultural do movimento de Jesus de Nazaré (1-33), destacando as dimensões políticas, sociais e culturais decorrentes de sua atuação e fundação de uma nova cosmovisão (Weltanschaung).
} 
império criaram as condições adequadas, aquilo que se chama de Kairós ou tempo oportuno, para que a semente das boas novas nascesse, se firmasse em bom solo, se desenvolvesse e se propagasse. Nessa direção:

[...] o êxito histórico do Cristianismo [deu-se] no crítico momento da decadência do mundo antigo, configurada na decadência dos grandes impérios dos quais o império romano é síntese e principal exemplo. Contudo, para entender como se passa esta transformação é preciso recuar ainda mais e captar o 'espírito' da crise que já se anunciava no epígono da grande civilização grega dominada pelos romanos. Podemos dizer que este período de crise se inicia por volta do século II a.C. e estende-se até o século V d.C. quando já estão consolidadas as sínteses estruturais básicas que sustentarão toda a Idade Média. Podemos dizer que efetivamente, é a partir do século $\mathrm{V}$ que se inicia um novo tempo e um novo mundo, mundo no qual a igreja organiza tudo e produz um imaginário social que lhe garante o real domínio tanto ideológico quanto real político. (NUNES, 1987, p. 38, grifo nosso).

A dimensão de universalidade da mensagem cristã é consequência da superação das características do mundo antigo, notadamente local, pela emergência do poderio cultural e bélico greco-romano. No entanto, os estados dominantes desenvolveram uma dimensão etnocêntrica, capaz de sustentar a categoria política de dominação. O universalismo de inspiração cristã, por sua vez, subverteria essa primeira dimensão política. Importante ressaltar que, em função das categorias que regem o pensamento teológico, a mensagem cristã evoca-se como universalista e democrática, ainda que esse conceito seja aproximativo.

Essa mensagem que nasceu em meio ao judaísmo, que se desenvolveu em meio às camadas mais populares e que, posteriormente, alcançou as pessoas mais nobres, como aponta o apóstolo Paulo ao citar 
conversão entre a elite do exército romano, se nutriu de um sentimento comum à época, algo que mistura o sincretismo religioso. No primeiro século existiam várias religiões e seitas no império, por isso o cristianismo progride sem muitos problemas, com um interesse genuíno pela busca da verdade, da alethéia, um sentimento que é nutrido por pessoas simples, mas, principalmente, pelos intelectuais.

De acordo com Cambi (1999), os primeiros intelectuais que se converteram ao cristianismo e vão se tornar apologistas da fé cristã são pessoas de grande cultura e formação que, ao buscar a verdade nas mais diferentes expressões filosóficas e religiosas (mitraísmo, taurobolismo, entre outras manifestações tidas como pagãs de religiosidade e de sincretismo), vão encontrar no cristianismo e no Cristo a verdade. Esse tipo de condição espiritual do homem do primeiro século é uma característica marcante do pensamento antigo e se estende, por exemplo, até Agostinho, cuja vida foi marcada pela busca da verdade, tendo ele passado por escolas como o maniqueísmo, o neoplatonismo e o ceticismo. (CAMBI, 1999).

\subsection{O desenvolvimento de uma Paideia Cristã}

Como já dissemos anteriormente, os gregos tinham uma concepção do homem que pretendiam formar. Essa visão, normalmente chamada de essencialista, comporta uma visão idealizada do homem fundada no desenvolvimento de suas virtualidades, por meio de determinadas virtudes. O cristianismo não se furta ao mesmo propósito ao ter uma concepção de homem e de contemplar a formação adequada desse "cidadão". Entretanto, os desafios do cristianismo enquanto projeto pedagógico são infinitamente maiores, em função do seu caráter universalista.

$\mathrm{Na}$ crença que se formou em meio ao judaísmo e se desenvolveu em meio às camadas mais populares, esse homem que se torna cristão, via de regra, não tinha cultura formal, não tinha conhecimentos elaborados. Falava uma linguagem rude, dos mercados, comum (daí o grego koiné ser a base dos textos dos evangelhos) e era, normalmente, analfabeto. Isso 
implicou um enorme esforço para levar adiante o processo de "ensinar" os elementos básicos dessa fé.

$\mathrm{Na}$ ausência de sinais alfabéticos pelos primeiros cristãos, são reconhecidos os usos de sinais visuais, semióforos, como símbolos da fé cristã (triângulo-trindade, alfa e ômega-início e fim, o desenho do peixe como expressão do acrônimo de christós, etc.), bem como o uso de credos (como elementos de síntese das principais crenças consideradas ortodoxas) e de afrescos e desenhos nos templos, para ensinar sobre os pontos principais da fé cristã. Temos, em meio a esse processo, os primórdios do que vamos denominar de paideia cristã. (COSTA NUNES, 2018).

Essa paideia vai se servir de elementos gregos que são inseridos na própria fé cristã, como, por exemplo, o texto dos Evangelhos, dirigido para a comunidade grega e que chegou a nós associado à figura do apóstolo João. Imerso em uma forte tradição filosófica grega, esse texto vai ser uma ponte entre a tradição judaica e, subsequentemente, a cristã, com os conceitos filosóficos que, afeitos às escolas gregas, assumem um novo significado em meio aos conteúdos da fé cristã, tornando-se fundamentais para essa nova educação do homem e seus valores. É possível dizer, então, que "a civilização grega exerceu uma profunda influência sobre a mentalidade cristã. Originalmente, o cristianismo foi um resultado da vida religiosa do judaísmo posterior.” (JAEGER, 2014, p.10)

Desse modo, a paideia cristã se coloca em outra lógica avessa à educação como o apanágio para o trabalho imediatamente. A paideia cristã parte da ideia de que pela educação nós formamos o homem, pela educação nós constituímos em plenitude a condição humana. A educação na paideia cristã é, então, uma prática social de hominização, de formação do homem para viver na sociedade terrena e celestial. Essa nova paideia consiste, pois, em ampliar a dignidade do homem para o que é atemporal e não espacial, daí a ideia de uma cidade terrena e uma outra divina, na qual o cristão, esse novo homem, participa em coparticipação.

Diferente da paideia grega, que visava, em sua tradição clássica, a formação do homem para a cidade, a partir de virtudes e habilidades cívicas, 
a paideia cristã, além dessa perspectiva (basta lembrar que entre os apologistas havia quem defendesse que a perseguição aos cristãos era contraproducente, pois não haviam melhores cidadãos, mais fiáveis e patrióticos que os cristãos), incluía uma concepção de homem diferenciada do pensamento grego. De acordo com o pensamento cristão, o homem não é tão somente visado enquanto corpo e razão, mas enquanto um ser cuja origem, sentido e destinação enquadram numa única perspectiva sub specie aeternitate. Ademais, o homem comporta em si uma imago dei, o que o diferencia do resto da criação e dá a ele uma dignidade superior e uma finalidade eterna. Este home não é somente o cidadão de uma cidade terrena, mas de uma civitas Dei. (COSTA NUNES, 2018).

\subsubsection{Da Cosmópolis a civitas Dei}

Da paideia grega, que tinha um aspecto cívico voltado para a cidade e para o exercício da politiká pelo polités (atividade que privilegiava valores e virtudes coletivas, mas que tinha o grupo social dos bem-nascidos como referencial, excluindo homens, mulheres, escravos, os muito jovens e os estrangeiros), passamos, já no período helenístico, para um tipo de atuação mais individual, muito embora mais universalista, uma vez que se abria a outros grupos sociais e mesmo estrangeiros. Essa nova abordagem tem uma dimensão coletiva estendida ao mínimo do espaço do grupo iniciado em uma determinada filosofia (estóicos, epicuristas), cujas virtudes expõem uma crise do homem com a pólis face ao amplo espaço e ao indiferenciamento da cosmópolis.

Face a essas contradições entre o período do coletivo, sucedido por outro voltado para o individual, temos, na antiguidade tardia ou cristã, o estabelecimento de um outro modelo que expressa outro tipo de civilidade e de individualidade. O cristianismo aponta para a formação do homem em seu aspecto individual, para valores diferenciados daqueles do período helenístico, mas que contemplam uma forma de comunidade mais ampliada que a desse período, uma vez que, para além da comunidade cristã 
localizada no tempo e no espaço, o cristão faz parte de uma comunidade universal, cathólika. Essa comunidade, mais categoricamente dizendo, congrega não somente diferentes pessoas de diferentes lugares, mas também uma comunidade universal, que é expressa por Agostinho na perspectiva de uma civitas Dei.

A dimensão universalista do cristianismo é ainda mais interessante, porque, nascido como uma seita dentro de uma seita - pelo menos era assim que os romanos consideravam o judaísmo e, por tabela, o cristianismo -, ele se expande e ultrapassa as fronteiras de um povo, de uma nação e de uma religião, tornando-se a mais universalista de todas as religiões, a mais aberta entre todas as nações e a mais acolhedora entre todos os povos, ultrapassando o aspecto espiritual para uma dimensão política diferenciada. Se os judeus almejam a Jerusalém terrena como um locus hereditário da promessa divina à Abraão, os cristãos herdarão a terra, espaço privilegiado para a transformação da civitas terrena na civitas Dei. Deste modo, o homem "[...] deve tomar consciência da sua viagem neste mundo, que é encaminhar-se para a civitas Dei, por entre quedas, retrocessos e interrupções, e combater o mal através do incremento da esperança e a expectativa da justiça ultraterrena de Deus.” (CAMBI, 1999, p. 137, grifos do autor).

A civitas Dei apresenta uma dimensão política, claro, mas também uma dimensão supra política, uma vez que sua universalidade realiza um projeto maior dentro da história e além dela, na perspectiva de uma criação. Além disso revela a dimensão de um escatón, para o qual o cristão deve, em ato contínuo, estar preparado e se preparando. Eis, de fato, nesse processo de preparação contínuo, o aspecto mais interessante da paideia cristã, uma vez que tal processo educativo não cessa nunca. Esse processo compreende virtudes e virtualidades que se aprimoram continuamente no tempo e no espaço, que visam não só o indivíduo, mas a coletividade, não só a coletividade mas a própria humanidade. Eis que o imperativo do Salvador continua sendo o mote dessa paideia cristã: "ide e pregai". 


\section{Considerações finais}

A expressão maior da paideia cristã compreende esse aspecto sintético que reúne os momentos singulares da educação clássica grega e do período helenístico em uma dimensão maior e mais estruturada, como também mais abrangente e universal do que até então se havia presenciado. Tais elementos vão ser fundamentais para o desenvolvimento da sociedade ocidental.

A despeito de que as culturas, sociedades e nações tenham se desenvolvido à revelia de um processo unificado, principalmente após a dissolução do Império Romano, é lógico que, com a universalização da religião cristã e de sua concepção de formação do homem, houve uma universalização de mentalidade (mutatis mutandis) que perpassou as sociedades oriundas da dissolução do império. Esse material comum universalizado pelo cristianismo poderíamos, sem dúvidas, considerar como uma visão da realidade, como uma cosmovisão ou, em termos mais pósmodernos, uma episteme:

Segundo Cambi (1999) o pensamento da educação como episteme, apresenta uma maior complexibilidade dos problemas educativos que se encontram fora da localidade, do determinismo cultural e ambiental, apresentando-se no processo de universalização racional, coloca em evidência a noção da paidéia que por milênios foi a base das reflexões educativas, reconstituindo-se como paidéia cristã, humanística e posteriormente como Bildung. (BORTOLINI, 2018, p. $34)$.

Tal concepção de educação nos torna herdeiros de um mesmo patrimônio cultural que tem uma dupla visão: grega e cristã ou, melhor dizendo, greco-romana e judaico-cristã. O mais importante é que, ao considerarmos essa herança, vamos nos sentir mais próximos de uma série de outra culturas que se nos assemelham por essa mesma concepção de realidade. Proximidade esta que comprova a vitalidade do universalismo 
cristão, uma vez que, segundo Bortolini (2018, p. 24) "nascemos numa determinada sociedade, somos tributários ou herdeiros de uma cultura ou civilização. Toda geração terá que repassar, para a geração posterior, os símbolos materiais e culturais da marcha histórica da humanidade”. E assim, como tributários e herdeiros, somos responsáveis por levar adiante e repassar essa cultura.

O reconhecimento da expressão da vitalidade dessa paideia cristã, mesmo em tempos de crise, de ateísmos, de radicalismos e de extremismos, é de vital importância não só para o cristianismo mas para a humanidade em geral, independente de credo, raça, cor, sexo, posição política ou o que quer que seja. A expressão do universalismo é um convite à tolerância, à participação em uma comunidade maior que as particularidades e singularidades. Nesse sentido, a civitas Dei, para além de um motivo religioso específico, é um convite a um processo educativo capaz de unir o humano em torno do divino. Para que isso se efetive, há que se ater ao imperativo mais importante da história humana: "ide, ensinai a todos".

\section{Referências}

BORTOLINI, Rosane Wandscheer. A paideia grega: aproximações teóricas sobre o ideal de formação do homem grego. Filos. e Educ., Campinas, SP, v.10, n.1, p.21-36, jan./abr. 2018.

CAMBI, Franco. História da pedagogia. São Paulo: Fundação Editora da UNESP (FEU), 1999.

COSTA NUNES, Ruy Afonso da. História da Educação na Antiguidade Cristã. Campinas: Kírion, 2018.

JAEGER, Werner Wilhelm. Paidéia: a formação do homem grego. São Paulo: Editora WMF Martins Fontes, 2013.

JAEGER, Werner Wilhelm. Cristianismo primitivo e paidéia grega. Santo André (SP): Academia Cristã, 2014.

LESKY, Albin. História da literatura grega. Lisboa: Fundação Calouste Gulbenkian, 1995.

Filos. e Educ., Campinas, SP, v.10, n.2, p.287-309, maio/ago. 2018 - ISSN 1984-9605 
MANACORDA, Mario Alighiero. História da educaşão: da antiguidade aos nossos dias. São Paulo: Cortez, 2010.

NUNES, César. A pedagogia cristã: ensinar a todos, aprender pelo amor. In: DASSOLER, Olmira Bernadete. Escolas católicas: uma gestão em rede para a longevidade da obra. Curitiba: Positivo, 2018.

NUNES, César. Aprendendo filosofia. Campinas: Papirus, 1987.

NUNES, César. O Direito à Educação como Direito: passos e descompassos da política educacional brasileira no limiar do terceiro milênio, 2018.

VIEIRA, Paulo Eduardo. A gênese da educação grega: da areté homérica à Paideia clássica. In: Filos. e Educ., Campinas, SP, v.10, n.1, p.166-183, jan./abr. 2018.

Submetido em: 01/09/2018

Aceito em: 04/10/2018

Publicado em: 15/10/2018

Filos. e Educ., Campinas, SP, v.10, n.2, p.287-309, maio/ago. 2018 - ISSN 1984-9605 